\title{
Molecular Characterization of Brazilian Strains of Xanthomonas campestris pv. viticola by rep-PCR Fingerprinting
}

\author{
Loiselene C. Trindade ${ }^{1 *}$, Mirtes F. Lima ${ }^{2}$ \& Marisa A. S. V. Ferreira ${ }^{1}$ \\ 'Departamento de Fitopatologia, Universidade de Brasília, CEP 70910-900, Brasília, DF, fax (61) 272-1793, e-mail: \\ marisavf@unb.br; ${ }^{2}$ EMBRAPA-Semi Árido, Cx. Postal 23, CEP 56300-970, Petrolina, PE
}

(Accepted for publication on 13/12/2004)

Corresponding author: Marisa A.S.Velloso Ferreira

TRINDADE, L.C., LIMA, M.F. \& FERREIRA, M.A.S.V. Molecular characterization of Brazilian strains of Xanthomonas campestris pv. viticola by rep-PCR fingerprinting. Fitopatologia Brasileira 30:46-54. 2005.

\begin{abstract}
Bacterial canker of grapevine (Vitis vinifera), caused by Xanthomonas campestris pv. viticola was first detected in Brazil in 1998, affecting grapevines in the São Francisco river basin, state of Pernambuco. The disease was also reported in Juazeiro, Bahia and later in Piauí and Ceará. Due to its limited geographical distribution and relatively recent detection in Brazil, very little is known about the pathogen's biology and diversity. Repetitive DNA based-PCR (rep-PCR) profiles were generated from purified bacterial DNA of 40 field strains of $X$. campestris pv. viticola, collected between 1998 and 2001 in the states of Pernambuco, Bahia and Piauí. Combined analysis of the PCR patterns obtained with primers REP, ERIC and BOX, showed a high degree of similarity among Brazilian strains and the Indian type strain NCPPB 2475. Similar genomic patterns with several diagnostic bands, present in all strains, could be detected. Fingerprints were distinct from those of strains representing other pathovars and from a yellow non-pathogenic isolate from grape leaves. The polymorphism observed among the Brazilian strains allowed their separation into five subgroups, although with no correlation with cultivar of origin, geographic location or year collected.

Additional keywords: diversity, grapevine bacterial canker, Vitis vinifera, repetitive DNA.

\section{RESUMO}

Caracterização molecular de isolados brasileiros de Xanthomonas campestris pv. viticola através de rep-PCR

O cancro bacteriano da videira (Vitis vinifera), causado por Xanthomonas campestris pv. viticola, foi primeiramente detectado no Brasil em 1998, em parreirais no município de Petrolina, Vale do São Francisco, Pernambuco. A doença foi também observada em Juazeiro, Bahia, e mais tarde nos estados de Piaú e Ceará. Devido à sua limitada distribuição geográfica e relativamente recente detecção no Brasil, pouco se conhece sobre a biologia e diversidade do patógeno. Padrões genômicos de rep-PCR foram gerados a partir do DNA purificado de 40 isolados de X. campestris pv. viticola, coletados entre 1998 e 2001, em diferentes localidades dos estados de Pernambuco, Bahia e Piaú. A análise combinada dos padrões obtidos com os "primers" REP, ERIC e BOX, mostraram alta similaridade entre os isolados brasileiros e o isolado tipo NCPPB 2475, originário da Índia. Os isolados brasileiros apresentaram padrões similares e algumas bandas diagnósticas, presentes em todos os isolados. Os padrões foram distintos dos isolados de outros patovares e de um isolado não-patogênico obtido de folhas de videira. $\mathrm{O}$ polimorfismo observado entre os isolados brasileiros permitiu a diferenciação de cinco subgrupos, sem nenhuma relação com cultivar de origem, local ou época de coleta.
\end{abstract}

Palavras-chave adicionais: diversidade, cancro bacteriano, Vitis vinifera, DNA repetitivo.

\section{INTRODUCTION}

In 1998, a new disease was reported affecting 'Red Globe' grapevines (Vitis vinifera L.) in Pernambuco and Bahia states. A gram-negative bacterium was isolated from all diseased plants and Koch's postulates were completed. The causal agent was identified through biochemical and pathogenicity tests as Xanthomonas campestris pv. viticola Nayudu (Dye) (Malavolta Jr. et al., 1999a; Lima et al., 1999). Later, the disease was also detected in the states of Piauí (Malavolta et al., 1999b) and Ceará (Freire \& Oliveira, 2001).

*Parte da Dissertação de Mestrado do primeiro autor. Universidade de Brasília (2002).
This bacterium forms typical non-pigmented, smooth, round, mucoid, convex colonies with entire margins. Diagnostic features of tested Brazilian strains were: gram-negative, metabolism strictly aerobic, urease and oxidase negative, asparagine not utilized as the sole source of carbon and nitrogen, tolerance up to $2 \% \mathrm{NaCl}$ and acid production from glucose, mannose, galactose, trehalose, cellobiose and fructose (Lima et al., 1999). Colonies were visible after 48 to $72 \mathrm{~h}$ at $28^{\circ} \mathrm{C}$ and $33^{\circ} \mathrm{C}$ (Lima et al., 1999), but no growth occurred at $41^{\circ} \mathrm{C}$ (Malavolta Jr. et al., 1999a). The hypersensitivity test was negative on tobacco (Nicotiana tabacum L.) leaves but positive on tomato (Lycopersicon esculentum Mill.) cv. "Santa Clara" (Malavolta Jr. et al., 1999a). Symptoms on grapevine 
plants could be detected from eight to 14 days after artificial inoculation depending on the method of inoculation used (Malavolta Jr. et al., 1999a; Lima et al.,1999).

Xanthomonas campestris pv. viticola was first described by Nayudu (1972) in India as Pseudomonas viticola Nayudu sp. nov., and its occurrence is apparently very restricted. Besides India, there are also reports of a "grapevine bacterial canker disease (GVBCD)" in Ukraine (Kochenko, 1993). Since the pathovar viticola has not been included in the reclassification work of Vauterin et al. (1995), its specific status may still be controversial. As with the pathovar mangiferaeindicae of the genus Xanthomonas, all strains could be referred to as members of the pathovar viticola. We chose here to use the name proposed by Dye (1978), considering that it has been used in all references to this disease found to date and until more information on their species classification is available.

Several molecular methods have been used to assess diversity and to detect plant pathogenic bacteria (Louws et al., 1999). The presence of repetitive DNA sequences is common in the prokaryotic and eukaryotic genomes. In bacteria, the observed occurrence of three families of repetitive sequences, REP, ERIC and BOX elements (Stern et al., 1984; Sharples \& Lloyd, 1990; Koeuth et al., 1995) led to the development of repetitive DNA PCR-based genomic fingerprinting protocols (referred as rep-PCR), in which primers were designed to amplify intervening DNA between two adjacent repetitive sequences (Louws et. al., 1999). The amplified fragments, then separated by electrophoresis on agarose gels, generate specific fingerprints (DeBruijn, 1992). Repetitive-PCR has been successfully used for identification and differentiation of strains and the assessment of genetic diversity of phytopathogenic bacteria such as Xanthomonas spp. and Pseudomonas spp. (Louws et al., 1994, 1995; Opgenorth et al., 1996; Weingart \& Volksch, 1997; Restrepo et al., 2000), Clavibacter michiganensis (Smith) Davis et al. (Louws et al., 1998), and Ralstonia solanacearum (Smith) Yabuuchi et al. (Horita \& Tsuchiya, 2001).

Due to its relatively recent detection in Brazil, little is known about the biology and diversity of $X$. campestris pv. viticola. The objective of this study was to compare several field strains of X. campestris pv. viticola, collected from 1998 to 2001, using rep-PCR fingerprinting. The molecular characterization of these isolates could provide information not only on their diversity but also on their origin. Specific fingerprints may also be helpful in the identification process leading to a more rapid and effective diagnosis of grapevine bacterial canker.

\section{MATERIALSAND METHODS}

\section{Bacterial strains: source and maintenance}

Forty grapevine bacterial canker-derived strains previously identified as $X$. campestris pv. viticola were used in this study (Table 1). Reference strain NCPPB 2475 (originated from India), another 18 Xanthomonas sp. strains from various host plants and one Ralstonia solanacearum strain were included for comparison purposes. One unidentified isolate, commonly isolated from grape leaves, was also included. This isolate grew on asparagine rich-medium, formed yellow, fastgrowing and gram-negative colonies and did not induce a hypersensitive reaction on tobacco leaves. All isolates were cultivated on Kado's 523 medium (Kado \& Heskett, 1970). For long-term maintenance, isolates were preserved on sterile distilled water at room temperature and frozen in $30 \%$ glycerol at $-80^{\circ} \mathrm{C}$.

\section{Biochemical and pathogenic characterization}

Initially all grapevine-derived isolates were identified and characterized according to conventional biochemical and physiological tests (Bradbury, 1986; Lelliott \& Stead, 1987; Schaad et al., 2001), except those obtained from other culture collections (IBSBF 1385, 1386 and 1369, and NCPPB 2475). The tests conducted were as described by Lima et al. (1999), except that the hypersensitivity test on tomato (cv. Santa Cruz), and growth on triphenyl tetrazolium chloride-containing medium (TTC) tests were included. All isolates were tested for pathogenicity by inoculation of petioles and leaves of grapevine cv. Catalunha after superficial wounding with a sterile needle.

\section{DNA isolation}

Total bacterial DNA was extracted using a modified version of the CTAB method from Ausubel et al. (1992). Single colonies grown on Kado's 523 medium were transferred to 1.5 $\mathrm{ml}$ of 523 liquid medium and cultures were grown at $28^{\circ} \mathrm{C}$, with shaking at $150 \mathrm{rpm}$. After $48 \mathrm{~h}$ the cultures were centrifuged at $4,600 \mathrm{~g}(8,000 \mathrm{rpm})$ for $5 \mathrm{~min}$, the supernatant was removed and the pellets were resuspended in $520 \mu \mathrm{l}$ of TE buffer $(10 \mathrm{mM}$ Tris-HCl, 1 mMEDTA, $\mathrm{pH} 8.0$ ). Fifteen microliters of $20 \%$ SDS and $3 \mu \mathrm{l}$ of Proteinase $\mathrm{K}(20 \mathrm{mg} / \mathrm{ml})$ were added. The mixture was incubated for 1 hour at $37^{\circ} \mathrm{C}$, then $100 \mu \mathrm{l}$ of $5 \mathrm{M} \mathrm{NaCl}$ and $80 \mu \mathrm{l}$ of a $10 \% \mathrm{CTAB}$ solution in $0.7 \mathrm{M} \mathrm{NaCl}$ were added and mixed. The suspension was incubated for $10 \mathrm{~min}$ at $65^{\circ} \mathrm{C}$ and kept on ice for $15 \mathrm{~min}$. An equal volume of chloroform:isoamyl alcohol (24:1) was added, followed by incubation on ice for 5 $\mathrm{min}$ and centrifugation at 7,200 $\mathrm{g}(10,000 \mathrm{rpm})$ for $20 \mathrm{~min}$. The aqueous phase was transferred to a new tube, 0.6 volumes of isopropanol were added and DNA was precipitated at $-20^{\circ} \mathrm{C}$ for $16 \mathrm{~h}$. DNA was collected by centrifugation at 7,200 $\mathrm{g}(10,000$ rpm) for $10 \mathrm{~min}$, washed with $500 \mu \mathrm{l}$ of $70 \%$ ethanol, air-dried at room temperature for approximately $3 \mathrm{~h}$ and finally resuspended in $50 \mu \mathrm{l}$ of TE buffer. The DNA was quantified on $0.8 \%$ agarose gels by comparison with DNA samples (phage $\lambda$ DNA-Hind III fragments) of known concentration, diluted to working aliquots of $50 \mathrm{ng} / \mu \mathrm{l}$ and stored at $-20^{\circ} \mathrm{C}$ until needed.

\section{Repetitive elements-based PCR (rep-PCR)}

Amplification reactions were conducted with three primer sets: (1) REP1R-I (5 'IIICGICGICATCIGGC 3') and REP2-I (5'ICGITTATCIGGCCTAC 3'); (2) ERIC1R (5' ATGTAAGCTCCTGGGGATTCA 3') and ERIC2 (5'AAGTAA GTGACTGGGGTGAGCG 3'), and (3) primer BOXA1R (5' 
TABLE 1 - Species and strains used in this study

\begin{tabular}{|c|c|c|}
\hline Strain & Host & $\begin{array}{l}\text { Location and year } \\
\text { collected }\end{array}$ \\
\hline $\begin{array}{l}\text { Xanthomonas campestris pv. viticola } \\
\text { NCPPB }^{\mathrm{a}} 2475 \\
\text { UnB }^{\mathrm{b}} 1183,1185,1186,1187,1188,1189,1190,1193,1194,1195, \mathrm{IBSBF}^{\mathrm{c}} 1369 \\
1191,1192 \\
\text { IBSBF } 1385 \\
\text { IBSBF } 1386 \\
\text { UnB } 1201,1202,1203,1206,1207,1208,1209 \\
\text { UnB } 1204 \\
\text { UnB } 1216,1218 \\
\text { UnB } 1205 \\
\text { UnB } 1210 \\
\text { UnB } 1211 \\
\text { UnB } 1212 \\
\text { UnB } 1213 \\
\text { UnB } 1214,1219,1220,1221 \\
\text { UnB } 1222 \\
\text { UnB } 1223,1224 \\
\text { UnB } 1225 \\
\text { UnB } 1226 \\
\text { UnB } 1227\end{array}$ & $\begin{array}{l}\text { Vitis vinifera } \\
\text { cv. Anabi-e-Shahi } \\
\text { cv. Red Globe } \\
\text { cv. Itália } \\
\text { cv. Itália } \\
\text { cv. Ribier } \\
\text { cv. Itália } \\
\text { cv. Red Globe } \\
\text { cv. Red Globe } \\
\text { cv. Itália } \\
\text { cv. IAC } 572 \text { (rootstock) } \\
\text { cv. Catalunha } \\
\text { cv. Itália } \\
\text { cv. Red Globe } \\
\text { cv. Catalunha } \\
\text { cv. Perlette } \\
\text { cv. Red Globe } \\
\text { cv. Festival } \\
\text { cv. Thompson Seedless } \\
\text { cv. Itália }\end{array}$ & $\begin{array}{l}\text { India, 1972 } \\
\text { Petrolina, PE, } 1998 \\
\text { Petrolina, PE, } 1998 \\
\text { Teresina, PI, } 1998 \\
\text { Teresina, PI, 1998 } \\
\text { Petrolina, PE, } 2000 \\
\text { Juazeiro, BA, } 2000 \\
\text { Petrolina, PE, } 2000 \\
\text { Sobradinho, BA, } 2000 \\
\text { Petrolina, PE, 2000 } \\
\text { Petrolina, PE, } 2000 \\
\text { Petrolina, PE, } 2001 \\
\text { Petrolina, PE, } 2001 \\
\text { Petrolina, PE, } 2001 \\
\text { Petrolina, PE, } 2001 \\
\text { Juazeiro, BA, } 2001 \\
\text { Petrolina, PE, } 2001 \\
\text { Petrolina, PE, } 2001 \\
\text { Petrolina, PE, } 2001\end{array}$ \\
\hline $\begin{array}{l}X \text {. axonopodis pv. glycines } \\
\text { UnB } 306\end{array}$ & soybean & Planaltina, DF,1983 \\
\hline $\begin{array}{l}\text { X. axonopodis pv. manihotis } \\
\text { UnB } 1126 \\
\text { UnB } 1114 \\
\text { UnB } 1111 \\
\text { UnB } 1129\end{array}$ & $\begin{array}{l}\text { cassava } \\
\text { cassava } \\
\text { cassava } \\
\text { cassava }\end{array}$ & $\begin{array}{l}\text { Jataí, GO, } 1996 \\
\text { Mirador, PR,1996 } \\
\text { Paranavaí, PR,1996 } \\
\text { Rolândia, PR, } 1996\end{array}$ \\
\hline $\begin{array}{l}\text { X. axonopodis pv. passiflorae } \\
\text { UnB } 642 \\
\text { X. axonopodis pv. ricini } \\
\text { UnB } 607 \text { (white colonies) }\end{array}$ & passionfruit & $\begin{array}{l}\text { Planaltina, DF, } 1986 \\
\text { Ibiapina,CE, } 1985\end{array}$ \\
\hline $\begin{array}{l}\text { X. campestris pv. campestris } \\
\text { UnB } 159 \\
\text { UnB } 606\end{array}$ & $\begin{array}{l}\text { cabbage } \\
\text { cabbage }\end{array}$ & $\begin{array}{l}\text { Vargem Bonita, DF, } 1981 \\
\text { Guaramiranga, CE, } 1985\end{array}$ \\
\hline $\begin{array}{l}\text { X. campestris pv. carotae } \\
\text { UnB } 107\end{array}$ & carrot & Vargem Bonita, DF, 1981 \\
\hline $\begin{array}{l}\text { X. campestris pv. mangiferaeindicae } \\
\text { UnB } 769 \text { (yellow) } \\
\text { UnB } 764 \text { (white) } \\
\text { IBSBF } 1230 \text { (white) } \\
\text { IBSBF } 1508 \text { (white) }\end{array}$ & $\begin{array}{l}\text { mango } \\
\text { mango } \\
\text { mango } \\
\text { cashew }\end{array}$ & $\begin{array}{l}\text { Planaltina, DF, } 1990 \\
\text { Planaltina, DF, } 1990 \\
\text { Brasil,1996 } \\
\text { Brasil,1999 }\end{array}$ \\
\hline $\begin{array}{l}\text { X. campestris pv. vesicatoria } \\
\text { UnB } 604 \\
\text { UnB } 605 \\
\text { UnB } 1174\end{array}$ & $\begin{array}{l}\text { tomato } \\
\text { tomato } \\
\text { pepper }\end{array}$ & $\begin{array}{l}\text { Ibiapina, CE, } 1985 \\
\text { CE, } 1985 \\
\text { DF, } 1998\end{array}$ \\
\hline $\begin{array}{l}\text { X. melonis } \\
\text { UnB1080 }\end{array}$ & cucumber & Vargem Bonita, DF, 1995 \\
\hline $\begin{array}{l}\text { Ralstonia solanacearum } \\
\text { UnB } 486 \\
\text { unidentified non-pathogenic isolate (NI) }\end{array}$ & $\begin{array}{l}\text { potato } \\
\text { Vitis vinifera } \mathrm{cv} \text {. Catalunha }\end{array}$ & $\begin{array}{l}\text { Lagoa Seca, PB, } 1984 \\
\text { Petrolina, PE, } 2001\end{array}$ \\
\hline
\end{tabular}

a National Collection of Plant Pathogenic Bacteria, York, UK.

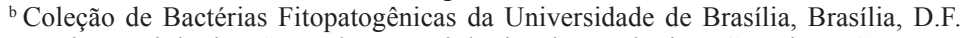

c Instituto Biológico Setor de Bacteriologia Fitopatológica, Campinas, S.P.

CTCCGGCAAGGCGACGCTGAC 3'), corresponding to REP, ERIC and BOX elements, respectively (Louws et al., 1999). Primers were synthesized by Life Technologies do Brasil Ltda. Each reaction consisted of: $1.2 \mu \mathrm{l}$ of $10 \mathrm{X}$ Taq buffer $(500 \mathrm{mM}$ $\mathrm{KCl}, 100 \mathrm{mM}$ TrIS-HCl); $1 \mathrm{mg} / \mathrm{ml} \mathrm{BSA} ; 1.5 \mathrm{mM} \mathrm{MgCl} ; 0.2 \mathrm{mM}$ each dNTP(GIBCO, BRL); $2 \mu \mathrm{M}$ of each primer, $1.25 \mathrm{U}$ of Taq DNA polymerase (GIBCO, BRL) and $50 \mathrm{ng}$ of bacterial DNA, in a final volume of $12 \mu$ l.

The PCR was carried out in a Gene Amp-PCR System 2400 thermal cycler (Applied Biosystems). With REP primers, REP1R-I and REP2-I, amplification began with a denaturation step at $95^{\circ} \mathrm{C}$ for $7 \mathrm{~min}$, followed by 35 cycles of $94^{\circ} \mathrm{C} / 1 \mathrm{~min} ; 44$ ${ }^{\circ} \mathrm{C} / 8 \mathrm{~min}$, and $65^{\circ} \mathrm{C}$ for $8 \mathrm{~min}$. With ERIC and BOX primers, cycling programmes started with denaturation at $95^{\circ} \mathrm{C}$ for 7 
min, followed by 30 cycles of: $94^{\circ} \mathrm{C} / 1 \mathrm{~min} ; 1 \mathrm{~min}$ at $52^{\circ} \mathrm{C}$ (ERIC) or $53^{\circ} \mathrm{C}(\mathrm{BOX})$ for primer annealing, and $8 \mathrm{~min}$ at $65^{\circ} \mathrm{C}$ for primer extension. After the extension step, the temperature was held at $65{ }^{\circ} \mathrm{C}$ for $15 \mathrm{~min}$ for all three primer sets. For each bacterial strain, reactions were repeated at least twice.

The PCR products were separated by electrophoresis on $1.5 \%$ agarose gels. Total volume of the reaction $(12 \mu \mathrm{l})$ was analyzed. Electrophoresis was carried out at $80 \mathrm{~V}$ for $4 \mathrm{~h}$ in 0.5 $\mathrm{X}$ Tris-borate EDTA buffer. Gels were stained with ethidium bromide $(0.5 \mu \mathrm{g} / \mathrm{ml})$, and DNA migration patterns were analyzed visually. Sizes of fragments were determined by comparison with DNA molecular weight markers, $1 \mathrm{~Kb}$ and $100 \mathrm{bp}$ DNA ladders (GIBCO, BRL).

Genomic fingerprint comparisons among bacterial strains were performed by measurement of band sizes. The presence or absence of each band was converted into binary data, scored as 1 for presence, and 0 for absence. Only the reproducible bands ranging from $200 \mathrm{bp}$ to $3 \mathrm{~kb}$ were scored for each strain. Data generated with the three sets of primers were combined and analyzed using software MVSP 3.1 (Kovach, 1999). Genetic relationships among isolates were determined by Jaccard's similarity coefficients followed by UPGMA (unweighted pair-group method using arithmetic averages) clustering analysis. The reliability of the dendrograms was assessed by bootstrap analysis (Swofford \& Olsen, 1990) with the software program WinBoot (Yap \& Nelson, 1996) with 1,000 repeated samplings.

\section{RESULTS}

All 37 field strains dated from 1998-2001, isolated from $V$. vinifera plants with bacterial canker symptoms showed biochemical properties of the genus Xanthomonas (Schaad et al., 2001) and, apart from colony color, they could not be differentiated from a $X$. campestris pv. campestris (Pammel) Dowson strain (UnB 159) through biochemical and physiological tests. The pathogenicity assay on grape leaves and petioles along with the biochemical characteristics, confirmed the identity of all strains as the pathogen described by Nayudu (1972).

The DNA amplification from $41 X$. campestris pv. viticola strains with primers REP, ERIC and BOX (rep-PCR) showed multiple fragments varying from $190 \mathrm{bp}$ to $3054 \mathrm{bp}$. Initially, several tests with REP primers were carried out in order to assess the reproducibility of the method with purified DNA and whole cells collected directly from agar or liquid cultures grown for 24-48 h. The cells were resuspended in sterile water and $1 \mu \mathrm{l}$ was used in the amplification reaction. The REP-PCR banding patterns were reproducible only when purified DNA was used. Only the major and more intense bands of $1 \mathrm{~kb}$ and $600 \mathrm{bp}$ were visualized when using whole cells in the amplification reactions. With purified DNA, the same electrophoretic patterns were produced from independent amplification reactions and also from two independent DNA extractions of the same strain (data not shown).

With ERIC primers, 19 bands varying from 190-3054 bp were visualized and scored (Figure 1). The majority of strains and the type strain NCPPB 2475 showed a similar pattern overall (Figure 1A), with several diagnostic bands. Polymorphic bands were also observed, and nine patterns could be differentiated. The genomic patterns of $X$. campestris pv. viticola were visually distinct from a non-pathogenic isolate (NI) and other xanthomonads (Figure 1B).

With primer BOXA1R a total of 12 bands varying from 210 bp to 2,036 bp were scored. An 800 bp-fragment was observed in the amplification patterns of $38 X$. campestris $\mathrm{pv}$. viticola strains. However, strains UnB 1212, 1222 and 1227 did not present that band. Visual analysis of the BOX fingerprinting patterns revealed five distinct patterns among the grape strains. Polymorphic bands were mostly detected in the region of 600-1000 bp. A high degree of similarity between Brazilian strains and the Indian strain was also observed (Figure 2).

The REP primers produced 16 scoreable bands ranging from 250 to $2900 \mathrm{bp}$. Seven distinct patterns were observed among $X$. campestris pv. viticola strains, with a $1,000 \mathrm{bp}$-band present in all strains. Polymorphism was observed between bands of 500 and $1000 \mathrm{bp}$.

The PCR products of all 41 pathovar viticola strains, regardless of the geographic location, host cultivar or year collected, showed an overall homogeneous pattern sharing multiple bands (Figures 1 and 2). For all three primers used, the non-pathogenic yellow strain (NI) showed a distinct banding pattern from the Xanthomonas spp. strains.

Considering only the grapevine-derived strains and the combined data from the three primer sets, two distinct groups could be differentiated at $26 \%$ similarity: group 1 , formed by the non-pathogenic strain (NI) only, and group 2, comprising all pathovar viticola strains (Figure 3). At $68 \%$ similarity, five subgroups were detected among the pathogenic strains. Thirty-two strains, representing $78 \%$ of the strains, formed one single group, which included the type strain (NCPPB 2475), 27 strains from Pernambuco, the two strains from Piauí (IBSBF 1385 and 1386) and two strains from Bahia (UnB 1224 and 1205). Reference strain NCPPB 2475 showed above $80 \%$ similarity to 29 grapevine strains ( $\sim 73 \%$ of the tested strains).

Dendrograms obtained with each individual set of primers showed an overall similar pattern of separation when compared to the combined analysis (data not shown). Of the three sets of primers tested, BOX was the most conserved, identifying a smaller number of subgroups among the strains.

Pathovar viticola strains representing all geographic locations and different rep-PCR groups (Figure 3 ) were selected and compared with other Xanthomonas sp. strains, associated with different hosts and one $R$. solanacerum strain. The combined analysis of the patterns generated by BOX, ERIC and REP-PCR showed the separation into two groups at $15 \%$ similarity (Figure 4). The first group was composed only of Ralstonia solanacearum (UnB 486), the second and largest group included all xanthomonads and the 12 selected $X$. campestris pv. viticola strains. Three mango (Mangifera indica L.) strains of $X$. campestris pv. mangiferaeindicae (Patel, Moniz \& Kulkarni) Robbs et al., UnB 764 (white), UnB 

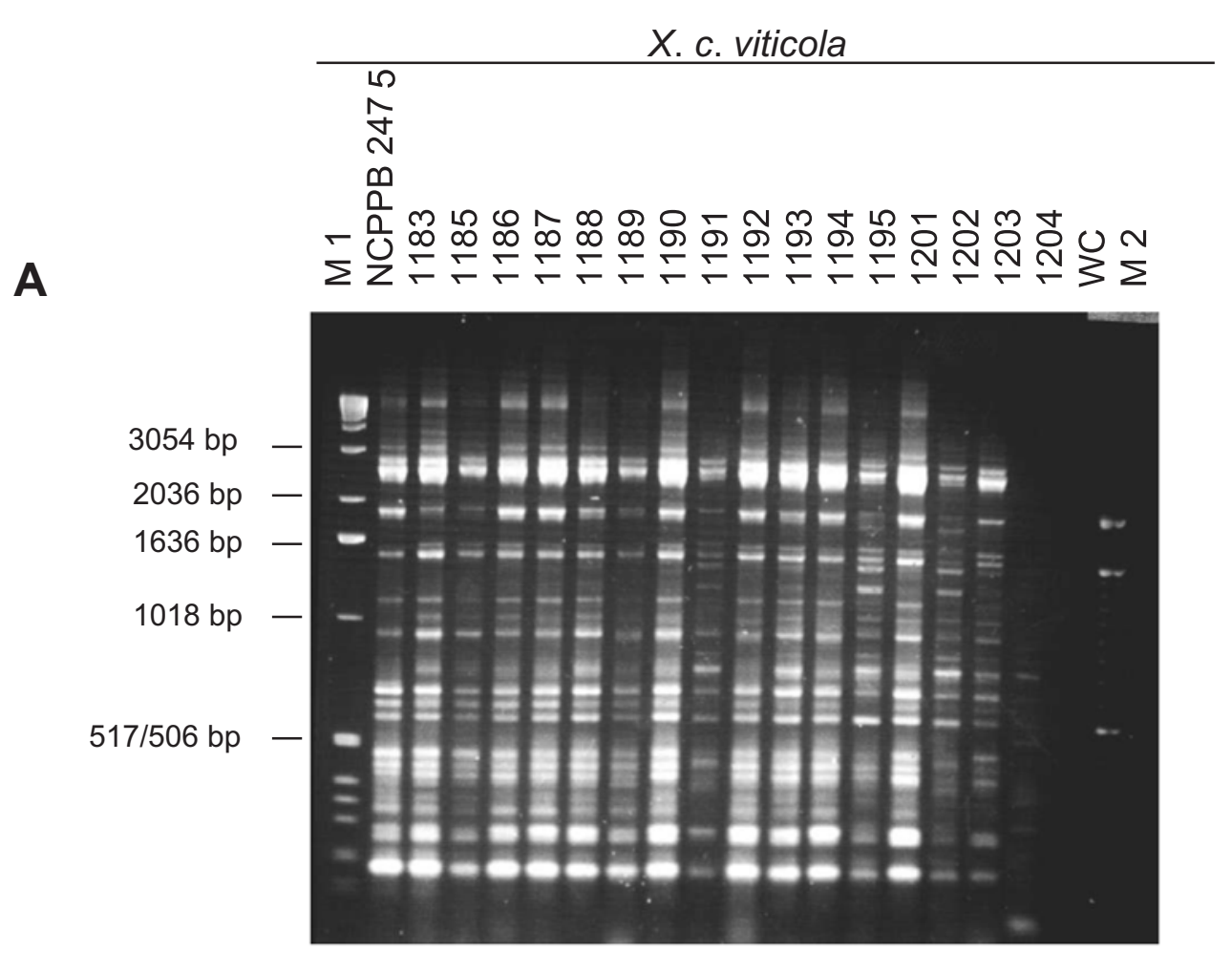

B

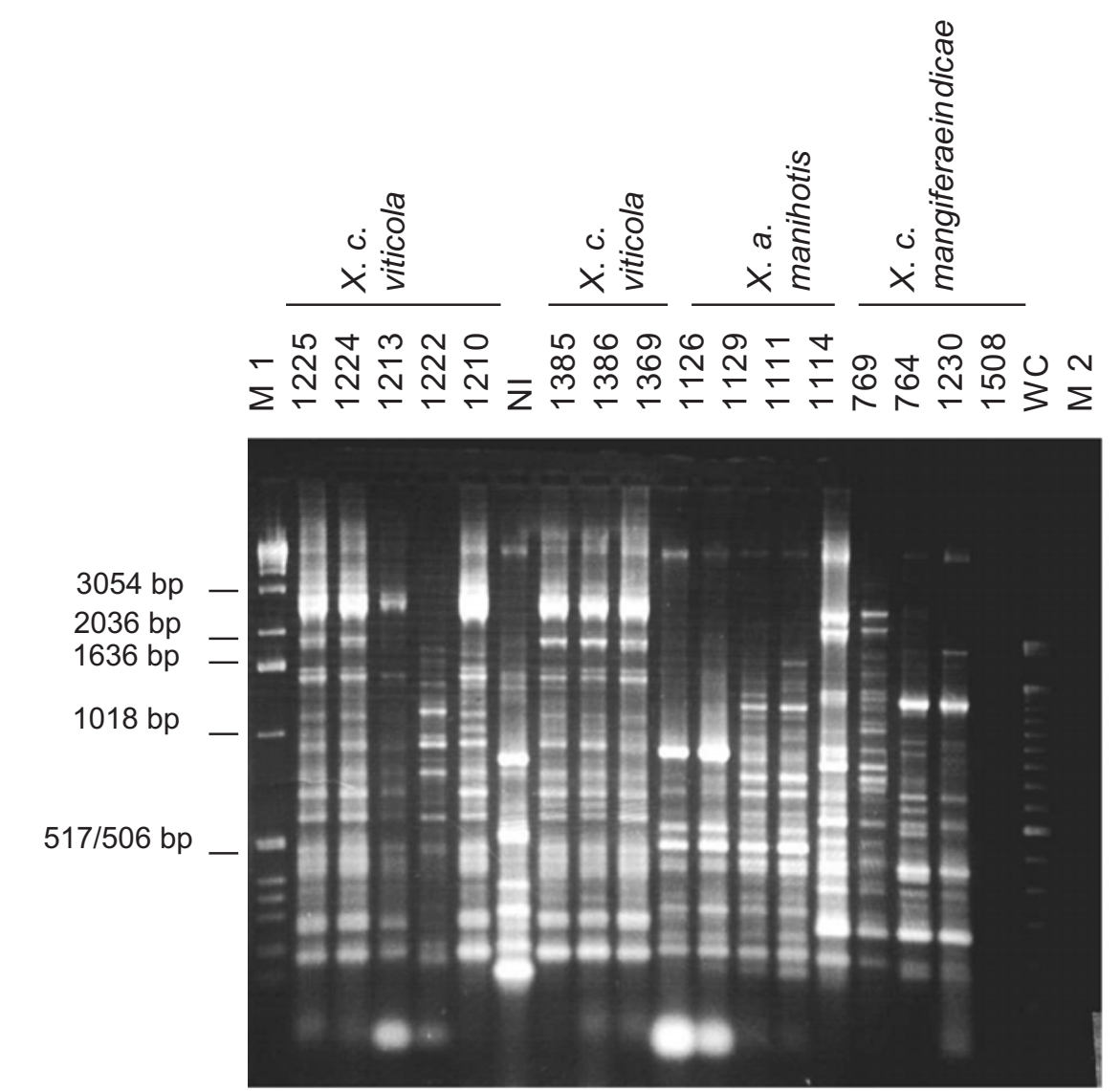

FIG. 1 - Genomic fingerprints of Xanthomonas spp. generated from ERIC-PCR. (A) field strains of X. campestris pv. viticola collected in Brazil compared to type strain NCPPB 2475. (B) field strains of X. campestris pv. viticola collected in Brazil compared to other Xanthomonas spp. from different host species. NI: unidentified strain; WC: water control; M: molecular size standards $1 \mathrm{~Kb}$ DNA ladder (M1) and 100 bp-DNA ladder (M2). PCR products were separated by electrophoresis on $1.5 \%$ agarose gels. 


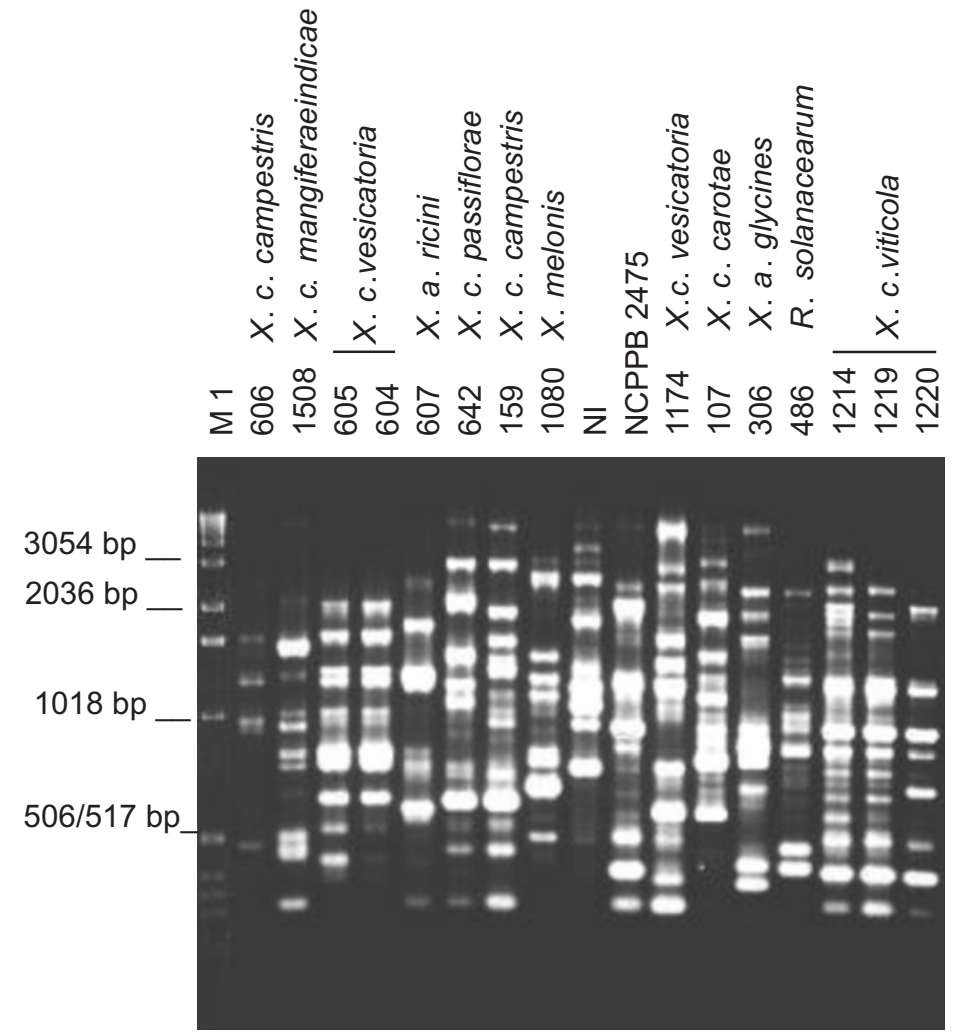

FIG. 2 - Genomic fingerprints of Xanthomonas spp. from various host species and four strains of $X$. campestris pv. viticola generated from BOX-PCR. Lane M1: molecular size standard ,1 Kb- DNA ladder; NI: unidentified strain. PCR products were separated by electrophoresis on $1.5 \%$ agarose gel.

769 (yellow) and IBSBF 1230 (white), showed the highest similarity to $X$. campestris pv. viticola. Among the $X$. campestris pv. mangiferaeindicae strains, the strain IBSBF 1508 (white) from cashew was the most divergent. All other xanthomonads were grouped separately with similarity levels below $36 \%$ in relation to the grapevine strains.

\section{DISCUSSION}

Reproducible genomic fingerprints were produced for all field strains of $X$. campestris pv. viticola, collected in three different years (1998, 2000 and 2001), different locations and isolated from different grape cultivars. Although most bands were present in all tested strains, there were differences in the intensity of some amplified fragments as well as in the occurrence of several polymorphic bands. The rep-PCR fingerprints clearly differentiated the grapevine strains from the $R$. solanacearum strain as well as from the unidentified yellow strain and members of other pathovars, all of which produced unique profiles (Figures 1 and 2). In the genus Xanthomonas, rep-PCR has revealed both inter and intrapathovar variability (Louws et al., 1994). For example, the studies of Louws et al. (1995) with Xanthomonas campestris pv. vesicatoria (Doidge) Dye., confirmed the separation of this pathovar into two genetically distinct groups, thus confirming the taxonomic studies of Vauterin et al. (1995). On the other hand, with primers REP and ERIC, a very high degree of homogeneity was found within a population of Xanthomonas fragariae Kennedy \& King, pathogenic on strawberries (Fragaria $x$ ananassa Duch.), collected during a four-yearperiod in California (Opgenorth et al., 1996). Louws et al. (1994) suggested that intrapathovar diversity in Xanthomonas spp. could be grouped into two categories: (i) pathovars from which isolates had almost identical fingerprints or had overall unique profiles but shared multiple bands, and (ii) pathovars from which isolates could be divided into groups and did not share common banding patterns. The Brazilian strains of the pathovar viticola characterized in this study were found to belong to the first category.

The ERIC-PCR revealed more polymorphic bands among the strains than the other two sets of primers. Other studies have also shown differences in the ability of primers to reveal diversity in Xanthomonas spp. The REP element, for example, was the most conserved and the less efficient in revealing polymorphism in X. campestris $p v$. vesicatoria group B strains (Louws et al.,1995). Within Xanthomonas axonopodis pv. manihotis (Bondar) Vauterin et al., both REP and ERIC primers showed a high level of polymorphism among strains originating from different edaphoclimatic zones in Colombia (Restrepo et al., 2000).

The great majority of field strains from Pernambuco, Piauí and Bahia, isolated from different cultivars over a three- 


\section{UPGMA}

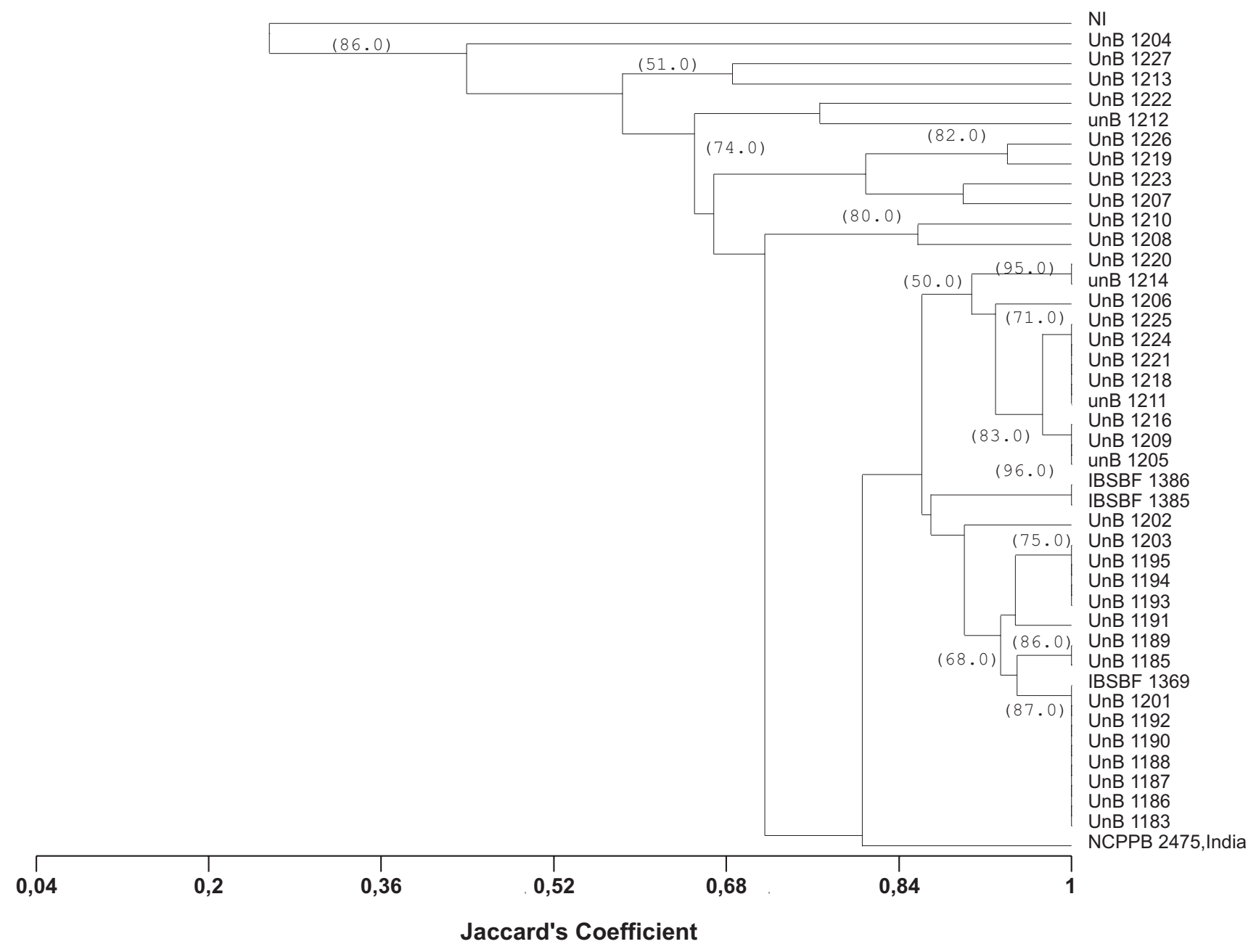

FIG. 3 - Phenogram based on Jaccard's similarity coefficients among 40 Xanthomonas campestris pv. viticola strains collected in Brazil along with the type strain (NCPPB 2475) from India and a non-pathogenic yellow strain from grape (Vitis spp.) leaves (NI). Cluster analysis was performed using the UPGMA method. Values greater than $50 \%$ in 1,000 bootstrap samples are placed on the branches.

year period, showed similarity values above $80 \%$ in relation to the Indian strain. Considering their biochemical and physiological properties, the Brazilian and Indian strains have shown the same characteristics (Nayudu, 1972; Lima et al., 1999; Araújo, 2001) except in the milk proteolysis test, which was negative for the strains from India studied by Chand \& Kishun (1990). The high genetic similarity between Brazilian isolates and the Indian type strain supports the hypothesis that this bacterium may have originated in India, and that it was disseminated and introduced through contaminated planting material (Robbs \& Rodrigues Neto, 1999). It is also possible that multiple introductions have occurred over time and/or that the bacterium may have been present in the country for a longer period, remaining undetected until the favorable climatic conditions of the summer of 1998 (Lima et al., 1999). The development of irrigation projects in the São Francisco basin, including Bahia and Pernambuco started in the 1970's (Araújo, 2001). Introduction and transit of planting material from other regions occurred and may have been responsible for the introduction of the bacterium. However, the lack of favorable environmental conditions may have prevented bacterial spread as the occurrence of an epidemic was not observed until 1998. Another hypothesis is that the bacteria may have been introduced by other potential hosts like mango and neem (Azadirachta indica A. Juss.). It is not known if the bacterium is naturally associated with these hosts in the area. Occurrence of symptomatic mango or neem plants has not been reported.

Xanthomonas campestris pv. viticola and $X$. campestris pv. mangiferaeindicae shared several bands and were found to be the most genetically similar. Both bacteria were originally described in India and are currently present in the northeast region of Brazil (Nayudu, 1972; Robbs et al., 1978). Some grapeproducing areas in the São Francisco basin also grow mango trees and use neem plants as wind-breakers. Both mango and neem have been reported as hosts of the pathovar viticola. It 
UPGMA

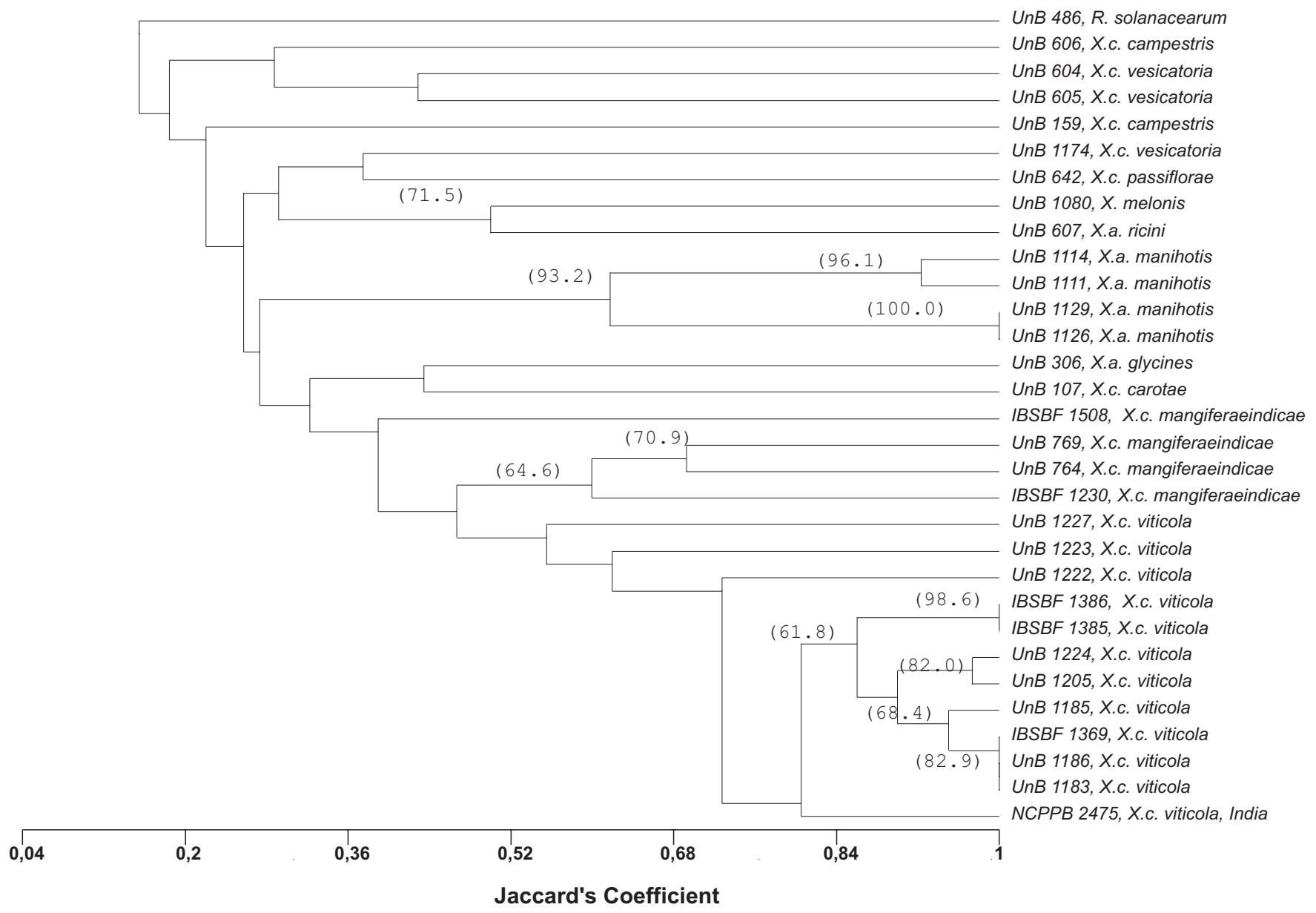

FIG. 4 - Phenogram based on Jaccard's similarity coefficients showing relationships between the Brazilian strains of Xanthomonas campestris pv. viticola, the type strain from India (NCPPB 2475) and other bacterial species and genera. Cluster analysis was performed using the UPGMA method. Values greater than $50 \%$ in 1,000 bootstrap samples are placed on the branches.

should be considered that the use of neem for protecting vineyards may also represent a source of genetic variation since this species can be naturally infected thus providing more inoculum for potential disease outbreaks (Nayudu, 1972; Nascimento et al., 2001).

The rep-PCR fingerprinting allowed us to identify $X$. campestris pv. viticola strains by the presence of several diagnostic bands present in all genomic fingerprints. Those bands were not present in the fingerprinting patterns of other pathovars, $R$. solanacearum, or the yellow strain associated with grape leaves. Intrapathovar variation was also detected and its significance should be further investigated with additional molecular markers. The lack of correlation between rep-PCR groupings and geographic origin of strains is an indication that this bacterium has spread among different vineyards in the Petrolina-Juazeiro area. Correlation between rep-PCR groupings and cultivar of origin or year of isolation were not evident either. The existing diversity in the pathovar viticola should be considered when adopting control measures based on selection of resistant material. Our study indicates that rep-PCR fingerprinting can be considered an important tool for identifying and monitoring the diversity of this pathogen in the affected areas.

\section{ACKOWLEDGEMENTS}

Project partially funded by Banco do Nordeste do Brasil. The authors wish to thank Wellington Moreira and Daniela Biaggioni Lopes at Embrapa Semi-Árido, Petrolina, Pernambuco, and CNPq for providing a scholarship to L.C. Trindade.

\section{LITERATURE CITED}

ARAÚJO, J.S.P. Perfil epidemiológico e subsídios para controle de Xanthomonas campestris pv. viticola (Nayudu) Dye, agente do cancro bacteriano da videira (Vitis vinifera L.) no Brasil. (Tese de Doutorado). Rio de Janeiro. Universidade Federal Rural do Rio de Janeiro. 2001.

AUSUBEL, F.M., BRENT, R., KINGSTON, R.E., MOORE, D.D., SEIDMAN, J.G., SMITH, J.A. \& STRUHL, K. (Eds). Short 
L.C. Trindade et al.

protocols in molecular biology. $2^{\text {nd }}$ ed. London. Jonh Wiley \& Sons Inc. 1992.

BRADBURY, J.F. Guide to plant pathogenic bacteria Kew. C.A.B. International. 1986.

CHAND, R. \& KISHUM, R. Outbreak of grapevine bacterial canker disease in India. Vitis 29:183-188. 1990.

DeBRUIJIN, F.J. Use of repetitive (Repetitive Extragenic Palindromic and Enterobacterial Repetitive Intergenic Consensus) sequences and polymerase chain reaction to fingerprint the genomes of Rhizobium meliloti isolates and other soil bacteria. Applied and Environmental Microbiology 58:2180-2187. 1992.

DYE, D.W. Genus IX Xanthomonas Dowson 1939. In: Young, J.M., Dye, D.W., Bradbury, J.F., Panagopoulos, C.G. \& Robbs, C.F. (Eds.). A proposed nomenclature and classification for pathogenic bacteria. New Zealand Journal of Agricultural Research 21:153-177. 1978.

FREIRE, F.C.O. \& OLIVEIRA, A.D.S. Ocorrência do cancro bacteriano da videira no Estado do Ceará. Comunicado Técnico, 62. Embrapa Agroindústria Tropical. 2001.

HORITA, M. \& TSUCHIYA, K. Genetic diversity of Japanese strains of Ralstonia solanacearum. Phytopathology 91:399-407. 2001

KADO, C.I. \& HESKETT, M. G. Selective media for isolation of Agrobacterium, Corynebacterium, Erwinia, Pseudomonas and Xanthomonas. Phytopathology 60:969-976. 1970.

KOCHENKO, Z-I. Development of canker tumours on grape roots. Zashchita-Rastenii-Moskva 7:42-43. 1993.

KOEUTH, T., VERSALOVIC, J. \& LUPSKI, J. R. Differential subsequence conservation of interspersed repetitive Streptococcus pneumoniae BOX elements in diverse bacteria. Genome Research 5:408-418.1995.

KOVACH, W.L. MVSP - Multivariate Statistical Package for Windows, Version 3.1 Pentraeth, Wales, UK. Kovach Computing Services. 1999.

LELLIOTT, R.A \& STEAD, D.E. Methods for diagnosis of bacterial diseases of plants. Oxford. Blackwell Science. 1987.

LIMA, M.F., FERREIRA, M.A.S.V., MOREIRA, W.A. \& DIANESE, J.C. Bacterial canker of grapevine in Brazil. Fitopatologia Brasileira 24:440-443. 1999.

LOUWS, F.J., FULBRIGHT, D.W., STEPHENS, C.T. \& DeBRUIJN, F.J. Specific genomic fingerprints of phytopathogenic Xanthomonas and Pseudomonas pathovars and strains generated with repetitive sequences and PCR. Applied and Environmental Microbiology 60:2286-2295. 1994.

LOUWS, F.J., FULBRIGHT, D.W., STEPHENS, C.T. \& DeBRUIJN, F.J. Differentiation of genomic structure by rep-PCR fingerprinting to rapidly classify Xanthomonas campestris pv. vesicatoria. Phytopathology 85:528-536. 1995.

LOUWS, F.J., BELL, J., MEDINA-MORA, C.M., SMART, C.D., OPGENORTH, D., ISHIMARU, C.A., HAUSBECK, M. K., DeBRUIJN, F.J. \& FULBRIGHT, D.W. rep-PCR-mediated genomic fingerprinting:a rapid and effective method to identify Clavibacter michiganensis. Phytopathology 88:862-868. 1998.

LOUWS, F.J., RADEMAKER, J.L.W. \& DeBRUIJN, F.J. The three Ds of PCR-based genomic analysis of phytobacteria:diversity, detection and disease diagnosis. Annual Review of Phytopathology
37:81-125. 1999.

MALAVOLTA JR., V.A., ALMEIDA, J.M.G., SUGIMORI, M.H., RIBEIRO, I.J.A., RODRIGUES NETO, J. \& NOGUEIRA, E.M.C. Ocorrência de Xanthomonas campestris pv. viticola em videira no Brasil. Summa Phytopathologica 25:262-264. 1999a.

MALAVOLTA JR., V.A., ALMEIDA, J.M.G., SUGIMORI, M.H., RIBEIRO, I.J.A., RODRIGUES NETO, J., PIRES, E.J.P. \& NOGUEIRA, E.M.C. Xanthomonas campestris pv. viticola em videira no Estado do Piauí. Summa Phytopathologica 25:1999b (Abstract).

NASCIMENTO, A.R.P., SILVA, V.A.V. MONTEIRO, L.C. AGUIAR, I.F. \& CASTRO, G.S.S. Azadirachta indica - Hospedeiro alternativo de Xanthomonas campestris pv. viticola no submédio do Vale do São Francisco. Fitopatologia Brasileira 26:282. 2001 (Abstract).

NAYUDU, M.V. Pseudomonas viticola sp. nov., incitant of a new bacterial disease of grapevine. Phytopathologische Zeitschrift 73:183186. 1972.

OPGENORTH, D.C., SMART, C.D., LOUWS, F.J., DeBRUIJN, F.J. \& KIRKPATRICK, B.C. Identification of Xanthomonas fragariae field isolates by PCR genomic fingerprinting. Plant Disease 80:868873. 1996.

RESTREPO, S., VÉLEZ, C.M. \& VERDIER, V. Measuring the genetic diversity of Xanthomonas axonopodis pv. manihotis within different fields in Colombia. Phytopathology 90:683-690. 2000.

ROBBS, C.F., da PONTE, J.J. \& SALES, M.G. Nota sobre Xanthomonas mangiferaeindicae no nordeste do Brasil. Fitopatologia Brasileira 3:215-218. 1978.

ROBBS, C.F. \& RODRIGUES NETO, J. Enfermidades causadas por bactérias em frutíferas tropicais no Brasil. Summa Phytopathologica 25:47-52. 1999.

SCHAAD, N.W., JONES, J.B. \& LACY, G.H. Xanthomonas. In: Schaad, N.W., Jones, J.B. \& Chun, W. (Eds.) Laboratory guide for identification of plant pathogenic bacteria. $3^{\text {rd }}$. ed. St. Paul. The American Phytopathological Society. 2001. pp. 175-200.

STERN, M.J., AMES, G.F-L., SMITH, N.H., ROBINSON, E. C., \& CHRISTOPHER, F.H. Repetitive extragenic palindromic sequences:a major component of the bacterial genome. Cell 37:1015-1026. 1984.

SWOFFORD D.L. \& OLSEN, G.J. Phylogeny reconstruction. In: Hillis, D.M. \& Moritz, C. (Eds.). Molecular systematics. Sunderland, USA. Sinauer Associates.1990. pp.411-501.

SHARPLES, G. J. \& LLOYD, R.G. A novel repeated DNA sequence located in the intergenic regions of bacterial chromosomes. Nucleic Acids Research 18:6503-6507.1990.

VAUTERIN, L., HOSTE, B., KERSTERS, K. \& SWINGS, J. Reclassification of Xanthomonas. International Journal of Systematic Bacteriology 45:472-489.1995.

WEINGART, H. \& VOLKSCH, B. Genetic fingerprinting of Pseudomonas syringae pathovars using ERIC-, REP-, and IS50-PCR. Journal of Phytopathology 145:339-345. 1997.

YAP, I.V. \& NELSON, R.J. WinBoot: a program for performing bootstrap analysis of binary data to determine the confidence limits of UPGMA-based dendrograms. Manila, Philippines. International Rice Research Institute. Discussion Paper Series no. 14. 1996. 